\title{
How to develop a community sanctuary - an experimental approach to the conservation of private lands
}

\author{
Robert H. Horwich
}

As human pressure on tropical forests grows, conservation needs new approaches. An experiment in conserving tropical rain forests on private lands on the Belize River is under way in Belize. Over 70 landowners have signed pledges to abide by a management plan devised for the conservation of the black howler monkey Alouatta pigra. The author discusses what was involved in creating the Community Baboon Sanctuary and how this approach could be used in similar projects to benefit both wildlife and local people.

Conservation in the past has tended to focus on preserving pristine areas or areas of specific biological interest. This is the first necessary step in conserving natural resources, but the methods may antagonize local people, especially if they are removed from the area. However, security of even these areas is becoming more dependent on the participation of local people, who may become hostile to conservation goals if they are not considered (Gregg and McGean, 1985). We must go beyond creating parks (Carr, 1988). It is now time to experiment with other methods of conservation, methods of multiple land use, and specifically methods that deal with private lands, since the majority of wild lands are private. Since such lands are under the control of local landowners, conservation projects involving private lands must include education as a major part of the programme. Many landowners understand both the freedom and responsibility of owning their own land, and conservation education should stress and build on this landethic responsibility.

The Community Baboon Sanctuary (baboon is the Creole name for howler monkey) (Horwich, 1986, 1988; Horwich and Lyon, 1987a, 1988) on the Belize River in Belize is an experiment in creating a sanctuary with the help of local farmers and landowners. It depends on their absolute co-operation, so it must meet their needs as well as those of the wildlife. Since the sanctuary is still untested on a long-term basis, similar attempts can use this paper as a guide, but should work with flexibility and creativity, gearing their project to the specific local situation. However, the basic concept of our experiment in Belize can have wide ramifications and applications in other countries, other cultures, and in other disciplines, such as with archaeological sites. The technique can also be used with buffer zones surrounding protected lands.

We asked private landowners to pledge to use their lands according to a management plan that we had drawn up to aid the black howler monkey. These management practices would also aid the landowners by reducing erosion of riverbanks and reducing the fallow time necessary for adequate nutritional buildup between slash-and-burn cultivation. As the project was experimental, we pursued each step with intuition and flexibility, based on feedback from the situation. The process of establishing the sanctuary fell into seven phases, mostly chronological, but often overlapping.

\section{Seven stages in establishing a community sanctuary}

\section{Identify an area for conservation}

The area may be established to protect a single endangered species, a specific ecotype, a corridor area linking other reserves or for some other reason. Our project focused on the black howler monkey, whose species status had been determined by Smith (1970), which we 


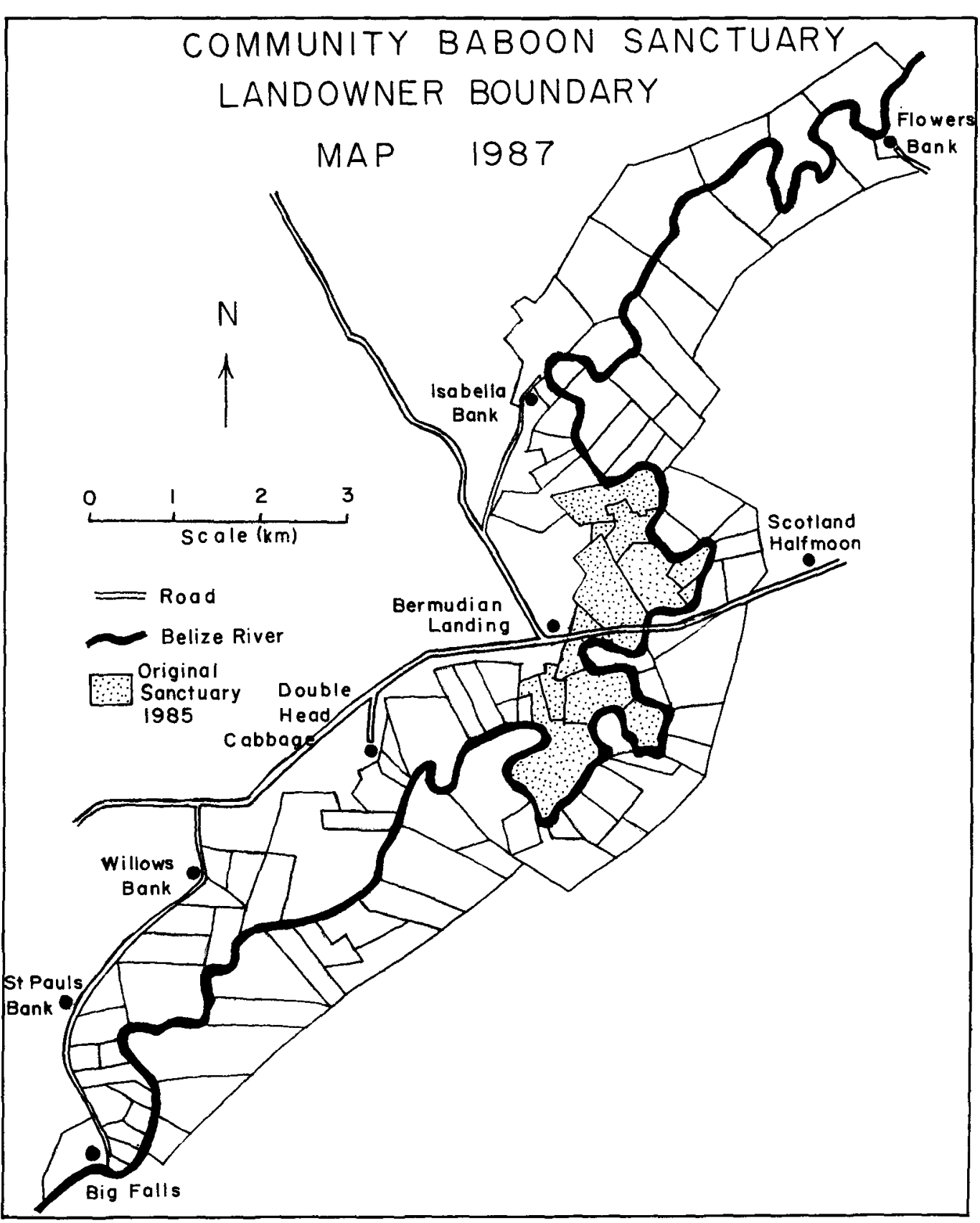

Figure 1. Map of land ownership boundaries in the Community Baboon Sanctuary, 1987.

confirmed (Horwich, 1983). A survey of its limited range (Horwich and Johnson, 1984, 1986) in Guatemala, Mexico, and Belize, showed that the area chosen for the Community Baboon Sanctuary had contained a high howler popu- lation for a long time and was continuous with other known and probable howler habitats. The local Creole people were favourably disposed towards the howlers; they did not eat them, considered them harmless (to crops) 
and enjoyed their presence in the area. The area was also accessible to visitors.

\section{Contact the local people}

Initial contact with local people should be done informally by talking with local landowners, village headmen or chairmen, teachers and other influential people. It is important to move slowly and with sensitivity, explaining why the land and particular wildlife species are valuable, and to gather feedback about the possibility of establishing a sanctuary. After contacting Village Council members and landowners, and detecting a positive attitude, we employed a sympathetic villager to help us gain written support in the form of a signed petition agreeing to our pursuing the sanctuary idea. Our village employee served two main functions: he lent us more credibility, gave villagers we approached a better sense of security, and bridged the cultural gap between us and the local populace; and knowing the individual community members, he was better able to explain and interpret what we were doing and why.

During this phase, although we promised nothing and had little to offer, we began to gather information about how the project might potentially benefit the local people. Although the area is relatively undeveloped with few amenities for tourists, villagers showed an interest in tourism, which they felt might bring in additional income.

\section{Formalize the plan}

Begin education about the programme at all levels, including one-to-one conversations with villagers, writing and distributing information, and giving school talks. I wrote and distributed a short illustrated booklet, Baboons of Belize, which stressed the howler monkey's vulnerability and importance as part of the natural heritage of Belize, and described what landowners could do to help. Using the petition from the villagers, we easily obtained approval from the Ministry of Natural Resources and the Area Representative who is also a Deputy Minister in the Government.
The local political structure, such as village or tribal meetings, can be used to bring the issue in front of the people. We introduced the idea of the sanctuary issue on to the agenda of the village meeting of Bermudian Landing at which the Area Representative was present. I explained to the villagers what we wanted to do and asked permission to proceed. The voluntary nature of the plan especially excited these rural landowners, who understood the importance and inherent independence of owning their own land. I also asked whether I should pursue attracting tourism to the area. Later, as we expanded the sanctuary, we approached other Village Councils and their community meetings in a similar manner. The Sanctuary Manager is now exploring the possibility of forming a council of Village Chairmen or other villagers in the area, both for the sanctuary and other common interests.

\section{Develop the site}

The core area of the prospective sanctuary can be mapped first, with the potential of expanding it later (Figure 1). The map should show habitat types, animal populations, successional growth stages, land use, and, most importantly, land ownership boundaries. Some help in doing this may be available from government survey offices or agricultural offices, but most will be obtained from neighbours and the landowners themselves. Aerial photographs are very helpful. We initially mapped a small area of good howler habitat along the river and censused the howler population.

It is important to work with the local people to help them achieve their goals. I began preparing the villagers for tourism by defining potential resources available. Villagers built a simple tourist shelter of local materials for campers and I solicited local families who were interested in providing tent sites, rooms and meals. Later we developed a community garden for local produce and tree propagation.

Education at all levels should be an ongoing process. I continued giving school lectures, distributing booklets, and holding informal discussions on conservation. We also wrote a guidebook (Horwich and Lyon, 1987b) as well 


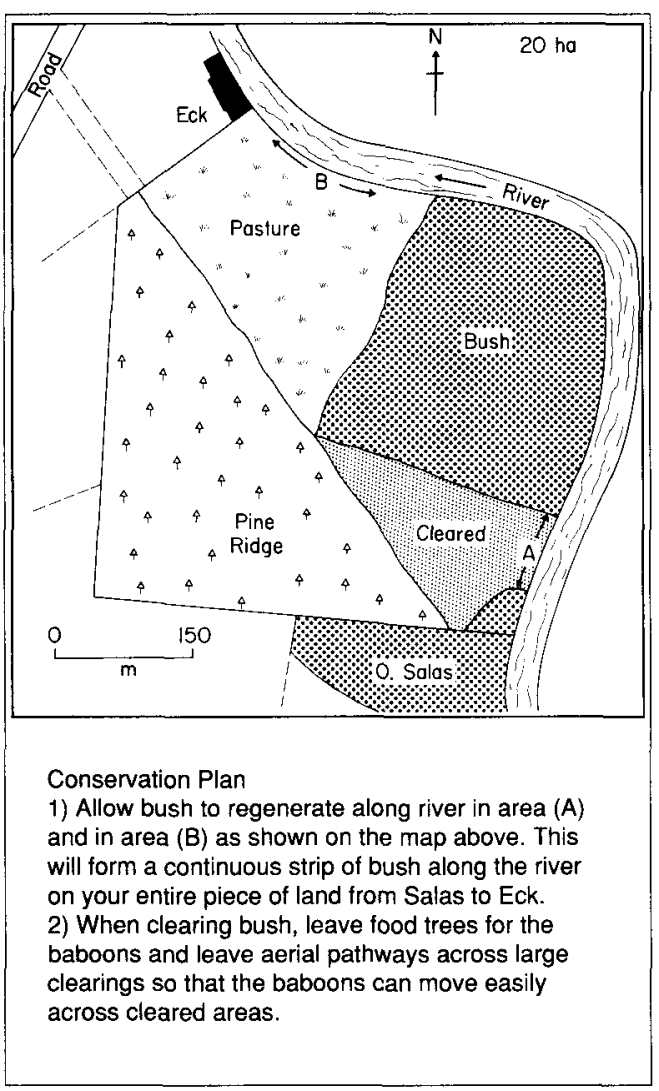

Figure 2. A Sample landowner map and management plan.

as school booklets on wildlife and tropical forests. The guidebook combines general information on tropical rain forests with specific information on the sanctuary flora and fauna (available for $\$ U S 5.00$ post-paid from the author).

Once a fairly accurate land ownership map has been drawn up, a management plan, specifically tailored to each land plot, can be written (Figure 2). This allows one to approach each landowner with specific requests. At first, ask for what you think they can give. We asked for simple things: to leave a strip of forest along the riverbanks, between land boundaries, and around farm plots, and to leave specific food trees, which were good for both howlers and livestock. If a specific area is particularly valuable, then explain why and see if they will leave it uncut. Ask whether the map is accurate and if there are any aspects of the plan that they cannot support. If they are in agreement with the map and plan, ask them to sign a voluntary pledge witnessed by a local person. The fact that the pledge is witnessed tends to have a positive social influence on the signer, encouraging him to abide by it. If anything is inaccurate, correct it and reapproach the landowner for signing. Later, give the landowner something to represent the signing. We gave each landowner a xeroxed map of their land and the signed management pledge. We also provided each landowner with a certificate of participation in the sanctuary (Horwich, 1986) and a T-shirt showing the primates of Belize. We arranged a ceremony with a local politician presenting the certificates to give country-wide acknowledgment to the landowners. Publicity and acknowledgment have provided really important feedback to potential signers. A radio programme about the sanctuary by the Belize Audubon Society made landowners eager to sign and participate.

As in the initial approach to villagers, it is important to use a local person who supports the project to help collect the voluntary pledges. Such as person should be knowledgeable about the wildlife, should know many local landowners, preferably be a landowner himself, and have prestige in the village.

\section{Publicize the sanctuary}

Publicize the project locally through news releases and through local radio and TV stations. Public talks can be given to local conservation groups, teachers and college classes. Additionally, talking with foreign tourist groups and alerting local tourist agencies about available resources will help if tourism is desired.

Following the publicity, preparations must be made for visitors. The resources available in the area must be defined. These may include guides, boats, restaurants, clubs, stores, hotels, camping areas etc. If these are not available, you must find people willing to meet some of those needs. We initially used teenaged boys with no permanent jobs, who worked for tips 


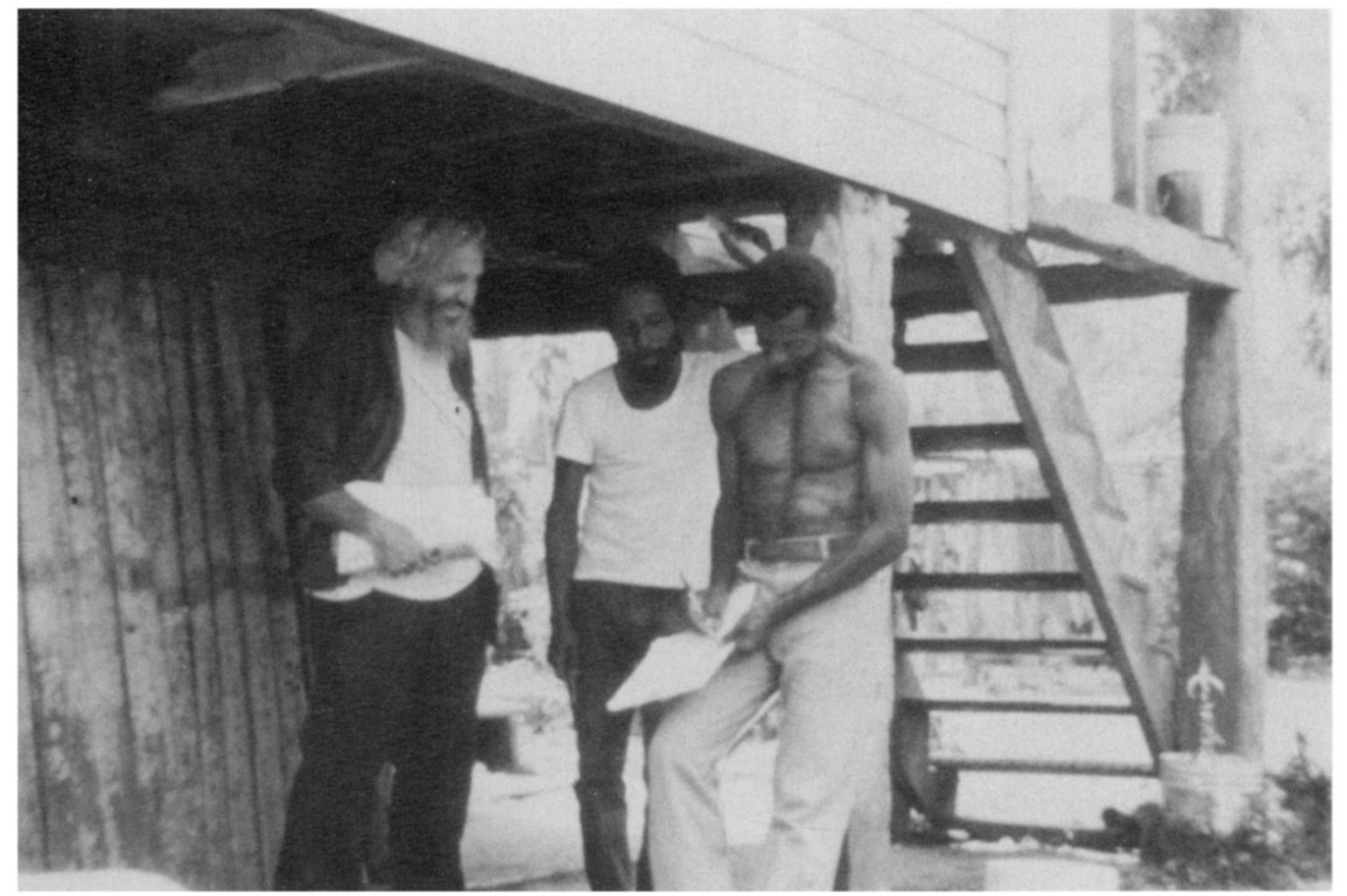

Dr Robert Horwich and Fallet Young witness a pledge-signing by a landowner.

from foreigners they took out on foot or in boats to see the howlers. Sanctuary staff now fulfil this function. We have been working with local families to provide a bed and breakfast' type of tourism, which includes a bed in a family's house or a place to camp and meals prepared by the family.

It is important to establish some formal or informal procedures for the sanctuary, which might include rules for tourists on private land, people they can contact on arrival, and rules and prices for local hosts when catering for tourists. We initially depended on the ferrymen at the entrance to the village to act as our information dispensers, since they informally functioned this way for the community. Tourists were given a few key names of villagers who could help them. We encouraged tourists to hire guides instead of wandering around the sanctuary on their own, in order to encourage the local economy, and to reduce the dangers to visitors. With the building of a bridge, tourists are now directed to the museum and the Sanctuary Manager who arranges for all needed services.

\section{Expand the sanctuary}

Once a core area has been established, move to outlying areas of similar habitat, using the same system that succeeded in the core area. Expand mapping to include the amount of land that seems feasible to manage and that forms a culturally and biologically similar region. We were approached by other villagers interested in participating in the sanctuary. We lived for a short while in areas where we were not known, to become more visible, to get to know the area, and to complete the mapping. The expanded sanctuary now includes riverine forest along a 32-km stretch of the Belize River, extending about $0.8 \mathrm{~km}$ on either side, which is prime howler habitat (Figure 1). The region is inhabited by a Creole population along a road that runs through five of the seven villages, and 
forms a sociological unit, with all people in the area sharing the same transport services. Most of the populace live on tongues of sandy pine forest, which were not included in the sanctuary. The sanctuary itself is composed of the villagers' farmland, which is riverine forest somewhat away from the living areas. We expect to expand the sanctuary to include all nearby howler habitat, which will connect two natural areas, a newly created waterbird sanctuary (Crooked Tree) in which howlers reside along the southern boundary, and Mussel Creek, which is a possible candidate for a traditional reserve. We initially established the sanctuary based on the co-operation of 12 landowners of Bermudian Landing in 1985 (Figure 1). It was rapidly expanded in 1986-87 to include over 70 landowners and six other villages. With the training of the Sanctuary Manager, Fallet Young, expansion of the sanctuary will include landowners of an eighth village, Scotland Halfmoon in Cohune Palm forests, extending east $10 \mathrm{~km}$ to Mussel Creek (Figure 1).

\section{Formalize a structure for a self-sustaining com- munity sanctuary}

In the final stage we first hired a local villager, Fallet Young, as the Sanctuary Manager; he has since hired a local assistant and another part-time employee. Their main job is, as the social conscience of the sanctuary, to remind landowners of the pledges they made, especially prior to the crucial slash-and-burn season. The success of the project lies with this staff who will perform four general functions in conservation, education, research and tourism. They lecture to local school classes and will try to stimulate conservation projects such as replanting riverbanks. They run a small rural museum for both local people and tourists. They gather data on the forest phenology, soil changes, and howler populations. We have formally set up the sanctuary under the auspices of the Belize Audubon Society to oversee and guide the sanctuary staff, which means that the sanctuary is under Belizean control at all levels. Start-up funds came from World Wildlife Fund-US and now the Zoological Society of Milwaukee County has agreed to maintain the sanctuary for the near future. At present it pays the salaries of the Sanctuary Manager and his assistant and the running expenses. We hope to arrange for the permanent maintenance of the sanctuary through a permanent sponsor or through raising a trust fund to generate yearly expenses.

\section{Future plans}

Following the earlier steps taken to establish the sanctuary, we have continued to add to the various steps to strengthen the four main sanctuary goals.

\section{Conservation}

We are continuing to monitor the howlers in the initial 1985 sanctuary. The population has increased by about 30 per cent from 1985 to 1989. We are continually monitoring tree-cutting through aerial photographs and landowner contacts, and estimate that about 90 per cent of the landowners are abiding by their pledges. Through a study of hunting of the river turtle Dermatemys mawii we hope to compose a conservation plan for the management of the species locally. We hope to monitor migratory bird populations and study bird communities to understand the effect of disturbed forests on northern migrants. We expect to replant or encourage regrowth of riverbank areas that have been cut. A longterm goal is to reintroduce hardwood tree species and specific game species.

\section{Education}

A recent documentary of the sanctuary was shown on Belize TV, which has stimulated interest. School class visits increased dramatically with sometimes hundreds of students visiting in a day. Without a reliable telephone service we are working to regulate these visits. We broadened the lecture programme to include rural and Belize City schools with more field classes using the labelled trail system. This trail, which is marked with numbered signs referring to the guidebook, is currently used in guided tours for 


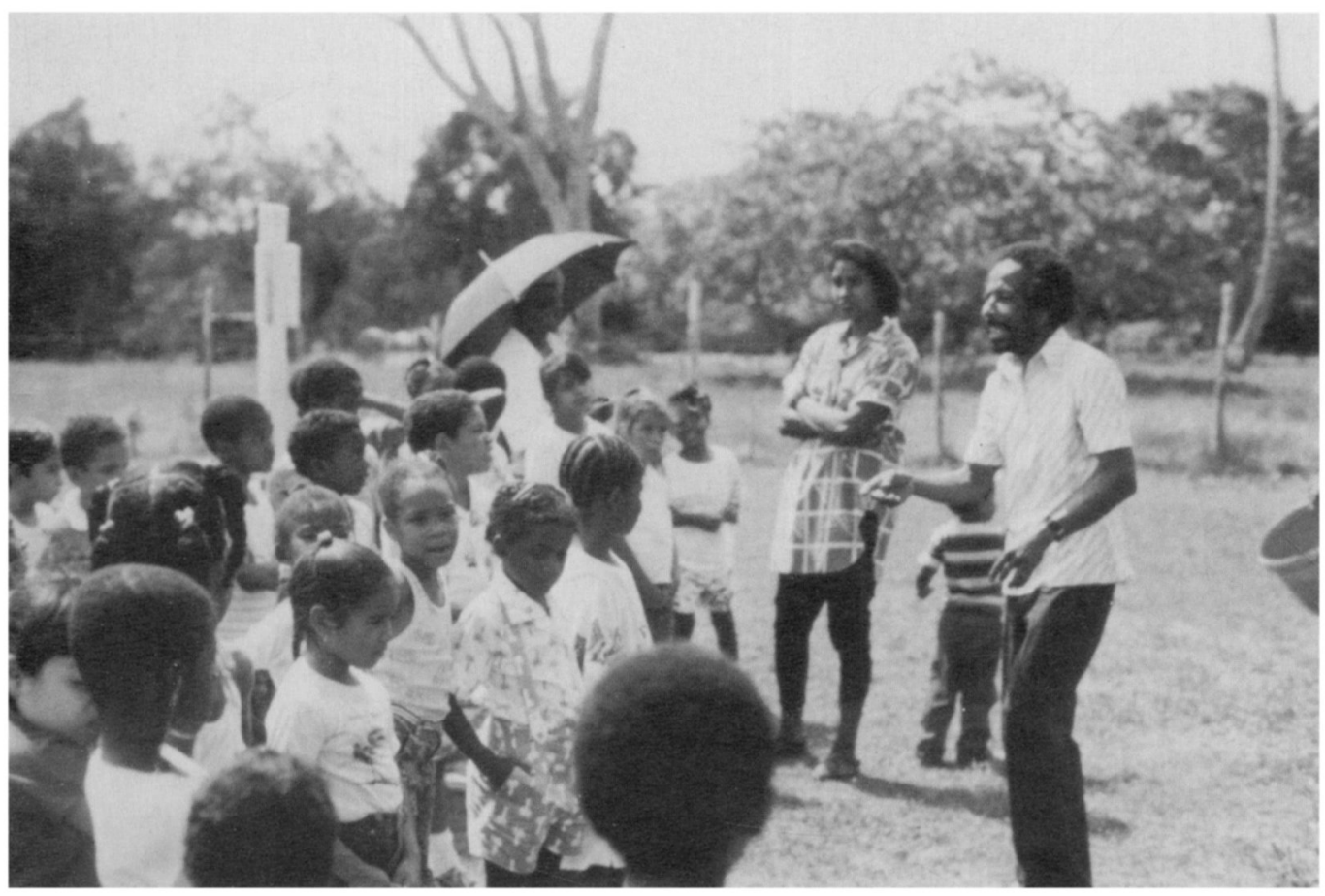

Fallet Young, Sanctuary Manager, lectures school children from Belize City at the Community Baboon Sanctuary.

Belizean and foreign tourists. The guidebook has been upgraded extensively and is now in the form of a text on the conservation and values of the local tropical forest and its wildlife. A small, rural museum has been built and opened with a series of low budget displays in 1989. These are laminated poster-style exhibits supplemented by local natural history and cultural materials. The emphasis is on the conservation of local flora and fauna and the Creole culture. Local plants are the basis of an arboretum and 'live' exhibits are encouraged by creating animal feeding, resting, and nesting areas within the arboretum.The museum opening in 1989 was a cultural, social, and media event with the dedication by a government minister, demonstration of rural crafts and woodlore, culminating in an evening dance. The large turnout is expected to increase Belizean use of the sanctuary.

\section{Research}

Research projects will be extended to provide information for sanctuary management and education, and to encourage researchers as long-term tourists who bring income into the villages. Projects include: succession of the riverine forest following slash-and-burn agriculture; seasonal ecology of the black howler monkey; hunting pressure on and reproductive biology of the river turtle Dermatemys mawii; pesticide and herbicide residues in river animals as a result of farming practices; study of Creole folk stories; kinship and sociology of a Creole village; survey of landowner views of conservation and the sanctuary experiment; survey of tourism in the Community Baboon Sanctuary; and reintroduction of the black howler monkey to established refuges in Belize.

\section{Tourism}

Currently we provide meals for campers and there are a few rooms available. The Sanctuary Manager co-ordinates tourists and their villager hosts. Meal and room rates are fairly regulated by sanctuary staff and villager partici- 
pants. We hope to establish small low-interest loans to a limited number of families to build tourist cabins for the use of tourists and researchers. Villagers will be selected by their contribution made to the sanctuary, their participation in tourism and their ability to build a cabin and repay the loan. The sanctuary will retain control of the cabins until the loan is repaid, at which time the cabins will be owned by the villagers. We are also making guided horseback and boat trips available through villagers' services.

Tourism has increased radically, making it necessary to try and regulate and control it. Visitors have increased from an estimated 2030 per year in 1985 and 1986 , to 200 people in 1987 , to 900 in 1988, and an estimated 20003000 in 1989 . Once tourist cabins are available, this increase will ensure an immediate improved economic benefit for the area.

\section{Acknowledgments}

The project has involved a number of volunteer participants in addition to the aid from local landowners and villagers. Jonathan Lyon has been instrumental in the sanctuary formation, performing much of the mapping and collecting of pledges. He has provided the botanical expertise, including research on forest succession stages and land use, and has helped write educational materials. Susan O'Connell, a Peace Corps Volunteer, has worked in public education and has gathered basic ecological data on the howlers. Barry Hartup has gathered data on villager response to the sanctuary, tourism, and howler populations. In addition, Ed Johnson helped with preliminary investigation of the sanctuary, Dail Murray publicized the project through her popular writings, and Jevra Brown helped in a variety of ways. Finally, both Fallet Young and Clifton Young were instrumental in sharing their knowledge and providing support in creating the sanctuary. The Belize Audubon Society, including members Jim and Lydia Waight and Mick Craig, have provided logistical support and guidance. Funding from 1985-88 was provided by World Wildlife Fund-
US. Current maintenance is provided by the Zoological Society of Milwaukee County. Additional funds for research and education have been provided by a grant from the Lincoln Park Zoological Society. Finally, I would like to thank all the villagers and landowners whose participation has led to the success of the sanctuary.

\section{References}

Carr, A. 1988. Beyond parks. Animal Kingdom, March/April, 12-24.

Gregg, W. P. and McGean, B. A. 1985. Biosphere reserves: their history and their promise. Orion Nature Quarterly, 4 (3), 40-51.

Horwich, R. H. 1983. Species status of the black howler monkey, Alouatta pigra, of Belize. Primates, 24, 288-289.

Horwich, R. H. 1986. A community baboon sanctuary in Belize. Primate Conservation, 7, 15.

Horwich, R. H. 1988. The Community Baboon Sanctuary: an approach to the conservation of private lands, Belize. In: Saving the Tropical Forests, (eds J. Gradwohl and R. Greenberg), Earthscan Publications Ltd, London.

Horwich, R. H. and Johnson, E. D. 1984. Geographic distribution and status of the black howler monkey. IUCN/SSC Primate Group Newsletter, March (4), 25-27.

Horwich, R. H. and Johnson, E. D. 1986. Geographical distribution of the black howler (Alouatta pigra) in Central America. Primates, 27, 53-62.

Horwich, R. H. and Lyon, J. 1987a. Development of the "Community Baboon Sanctuary" in Belize: An experiment in grass roots conservation. Primate Conservation, 8, 32-34.

Horwich, R. H. and Lyon, J. 1987b. Community Baboon Sanctuary, Belize, Orang-utan Press, Gays Mills, WI.

Horwich, R. H. and Lyon, J. 1988. An experimental technique for the conservation of private lands. $J$. Med. Primatol., 17, 169-176.

Smith, J. D. The systematic status of the black howler monkey, Alouatta pigra Lawrence. J. Mammal., 51, 358-367.

Robert H. Horwich, RD 1, Box 96, Gays Mills, WI 54631, USA. 